\title{
Comparative sequence analyses of the ribonuclease P (RNase P) RNA genes from LL-2,6- diaminopimelic acid-containing actinomycetes
}

\author{
Jung-Hoon Yoon and Yong-Ha Park
}

Environmental Bioresources Laboratory, Korea Research Institute of Bioscience and Biotechnology (KRIBB), PO Box 115, Yusong, Taejon, Korea
Author for correspondence: Yong-Ha Park. Tel: +8242860 4620. Fax: +82428604598. e-mail:yhpark@mail.kribb.re.kr

\begin{abstract}
Ribonuclease P (RNase P) RNA genes of LL-2,6-diaminopimelic acid (LL-A Pm)containing actinomycetes, except Streptomyces species, were sequenced after PCR-amplification and cloning. By using the sequence data, the relationships between species within genera and the relationships between taxa above genus level were investigated and the usefulness of the RNase P RNA gene as another phylogenetic marker was evaluated. RNase P RNA gene sequences of all strains used in this study contained relatively conserved regions along with highly variable regions. The mean RNase P RNA gene similarity value was approximately $82 \pm 18 \%$ and the mean RNase P RNA gene similarity value when gaps were included was approximately $76 \pm 24 \%$. The nucleotide similarities between the RNase P RNA genes of different strains were mostly fewer than the 165 rDNA similarities. The RNase P RNA gene was more useful than 165 rDNA for clearly differentiating the relationships between species belonging to a genus and the relationships between some genera. However, nucleotide sequences of RNase P RNA genes were not necessarily appropriate for comparisons at all taxonomic levels (such as those between species, between genera and between families).
\end{abstract}

Keywords: RNase P RNA gene, LL-2,6-diaminopimelic acid, actinomycetes, phylogeny

\section{INTRODUCTION}

The best means of investigating the genetic relationship between organisms is to compare their total genomic sequences. However, this approach is not likely to be possible without innovation in the existing molecular biological and analytical techniques. In the meantime, DNA-DNA hybridization and some useful gene fragments are used for elucidating genetic relationships or in phylogenetic studies. Such gene fragments include genes for rRNAs (Woese, 1987), the $\beta$-subunit of ATPsynthase (Amann et al., 1988), tRNA (Hofle, 1990), glutamine synthetase (Brown et al., 1994), elongation factor Tu (Kamla et al., 1996), a $65 \mathrm{kDa}$ heat-shock protein (hsp65) (Swanson et al., 1997) and a histonelike protein $(h b b)$ (Valsangiacomo et al., 1997). Among

Abbreviations: LL- $\mathrm{A}_{2} \mathrm{pm}$, LL-2,6-diaminopimelic acid; ITS, internally transcribed spacer.

The GenBank accession numbers for the sequences of the RNase P RNA genes determined in this study are listed in Table 1. these, 16S rRNA or 16S rDNA have been extensively studied and have become important as target genes in the phylogeny and classification of prokaryotic organisms (Woese \& Fox, 1977; Woese, 1987; Stackebrandt et al., 1997). Nevertheless, there is a general consensus that 16S rRNA gene sequences may be inappropriate for elucidating the relationships between closely related organisms and may be insufficient to guarantee species identity (Fox et al., 1992). DNA-DNA relatedness is generally recognized as being very important for defining species in current bacterial systematics (Wayne et al., 1987; Stackebrandt \& Goebel, 1994). However, despite the fact that it provides a decisive criterion in species definition, DNA-DNA reassociation also has some experimental problems, being affected by various factors such as DNA concentration, DNA purity, size of DNA fragments, incubation temperature, differences in the presence of RNA and so forth (Johnson, 1991); in addition, different methods are used to determine the levels of DNA-DNA relatedness (Vandamme et al., 1996). Therefore, quantitatively 
identical results are not always obtained. This also makes it difficult to construct databases using DNA-DNA relatedness results.

Although 16S rDNA sequencing and DNA-DNA relatedness tests are indispensable tools in current bacterial systematics, additional genetic markers also may be necessary to support the results of $16 \mathrm{~S}$ rDNA sequencing and DNA-DNA relatedness, in line with trends in polyphasic taxonomy. Recently, the sequences of the $16 \mathrm{~S}-23 \mathrm{~S}$ rDNA (16S-23S) internally transcribed spacer (ITS) have been shown to be useful for elucidating the relationships between closely related strains or species (Leblond-Bourget et al., 1996; Yoon et al., 1997a, 1998b). However, the 16S-23S ITS also has some disadvantages as a phylogenetic marker. The large variation in sequence and length of $16 \mathrm{~S}-23 \mathrm{~S}$ ITSs make it difficult to infer relationships between distantly related taxa (e.g. between taxa above genus level). Also, heterogeneities in sequence and length of 16S-23S ITSs within one organism have been found (Hain et al., 1997; Yoon et al., 1998b). Such heterogeneities, caused by the existence of multiple 16S-23S ITS alleles, may reduce the value of the 16S-23S ITS as a phylogenetic marker. Direct sequencing of heterogeneous PCR products of the 16S-23S ITS yields unreadable mixed sequence data above a certain position (Yoon et al., 1998b). If the extent of heterogeneity in sequence and length is to be determined, the PCR products should be cloned before sequencing is begun. However, because the numbers of rRNA gene clusters vary according to the organisms (Baylis \& Bibb, 1988; Pernodet et al., 1989; Yoon et al., 1996), it may not be easy to investigate the extent of the heterogeneity. Such heterogeneity within strains makes phylogenetic analysis of the 16S-23S ITS sequences rather complex.

Recently, the ribonuclease P (RNase P) RNA gene was evaluated for its potential as a new phylogenetic marker (Cho et al., 1998); its application to the study of the genus Saccharomonospora showed that it could possibly be used effectively in systematic studies. The mean nucleotide similarity of RNase P RNA gene sequences between Saccharomonospora species was intermediate between those values obtained from the sequences of 16S rDNA and the 16S-23S ITS (Cho et al., 1998). The members of the genus Saccharomonospora formed a single cluster distinct from some Gram-positive bacteria in a dendrogram based on comparative analysis of RNase P RNA gene sequences. Unlike the $16 \mathrm{~S}-23 \mathrm{~S}$ ITS, RNase P RNA is known to be encoded by a single-copy gene $(r n p B)$ in Gram-positive bacteria (Haas et al., 1996) and its size is relatively conserved (350-400 bp in bacteria; Pace \& Brown, 1995). Despite the potential of the RNase P RNA gene as an additional phylogenetic marker, few sequence data have been determined, especially for actinomycetes, and few systematic studies based on RNase P RNA gene sequences have been performed. Therefore, RNase P RNA gene sequences from diverse taxa including actinomycetes are necessary to evaluate its value as a marker for identification, classification and phylogeny. Such sequences will be used to extend RNase P RNA gene-based systematic studies to other genera. It is also necessary to investigate whether the RNase P RNA gene can be used to elucidate the relationships between distantly related taxa (such as those between genera or families).

In this study, LL-2,6-diaminopimelic acid (LL-A ${ }_{2} \mathrm{pm}$ )containing actinomycete taxa, except Streptomyces species, were chosen for extending the phylogenetic study based on RNase P RNA gene sequences. LL$\mathrm{A}_{2}$ pm-containing actinomycetes are a taxonomically and biotechnologically interesting group. Representatives of LL- $\mathrm{A}_{2}$ pm-containing coryneform and nocardioform actinomycetes, as well as the genus Streptomyces, have the ability to accumulate phosphate (Nakamura et al., 1995), to produce the antibiotic erythromycin (Miller et al., 1991) and to degrade some harmful aromatic compounds (Yoon et al., 1997c, 1999). Currently, LL-A ${ }_{2}$ pm-containing actinomycetes fall into five phylogenetic lineages, as shown by $16 \mathrm{~S}$ rRNA gene sequence analyses (Stackebrandt et al., 1997). The five lineages represent the following families (Stackebrandt et al., 1997): the family Nocardioidaceae comprises the genera Nocardioides (Prauser, 1976) and Aeromicrobium (Miller et al., 1991); the family Intrasporangiaceae comprises the genera Terrabacter (Collins et al., 1989), Terracoccus (Prauser et al., 1997) and Intrasporangium (Kalakoutskii et al., 1967); the family Propionibacteriaceae comprises the genera Propioniferax (Yokota et al., 1994), Luteococcus (Tamura et al., 1994), Microlunatus (Nakamura et al., 1995) and Friedmanniella (Schumann et al., 1997); the family Streptomycetaceae comprises a single genus, namely Streptomyces; and the family Sporichthyaceae comprises a single genus, namely Sporichthya (Lechevalier et al., 1968). In addition to genera such as Streptomyces, Intrasporangium and Sporichthya, which were described earlier, recently the numbers of LL- $\mathrm{A}_{2} \mathrm{pm}$-containing coryneform and nocardioform taxa have increased considerably. Nevertheless, until now, only approximately 22 validly described species of the 11 genera (except for the genus Streptomyces) have been validly described as LL-A ${ }_{2}$ pm-containing actinomycete taxa. There is evidence that LL-A $\mathrm{Pm}_{2}$ containing coryneform bacteria may be relatively common in nature and that the majority of such organisms have not been described (Collins et al., 1994; Keddie et al., 1966). LL-A ${ }_{2}$ pm-containing coryneform and nocardioform actinomycetes are important taxa that have received attention from the point of view of taxonomy, biodiversity and biotechnology. Therefore, additional useful taxonomic markers (whether genetic or chemotaxonomic) may be necessary to construct a polyphasic taxonomic approach to differentiating between existing LL-A ${ }_{2}$ pmcontaining taxa and to describing putative novel LL$\mathrm{A}_{2}$ pm-containing taxa.

The aim of this study was to investigate the relationships between taxa above genus level, as well as to 
study the interspecific relationships of LL- $\mathrm{A}_{2}$ pm-containing actinomycetes, using RNase P RNA gene sequences. LL- $\mathrm{A}_{2}$ pm-containing taxa were also used to determine if the RNase P RNA gene is appropriate for clarifying the phylogenetic relationships between distantly related organisms (e.g. between genera or families).

\section{METHODS}

Bacterial strains and culture conditions. Table 1 summarizes the strains used in this study. Most strains were grown in shake flasks containing trypticase soy broth (BBL) supplemented with glucose $(0 \cdot 75 \%, \mathrm{w} / \mathrm{v})$ at suitable temperatures. Propioniferax innocua was cultivated in shake flasks containing trypticase soy broth supplemented with yeast extract $(0.3 \%, \mathrm{w} / \mathrm{v})$ at $37^{\circ} \mathrm{C}$. Friedmanniella antarctica was cultivated in shake flasks containing R-medium at $22^{\circ} \mathrm{C}$. Microlunatus phosphovorus was cultivated in shake flasks containing microlunatus medium (Nakamura et al., 1995) at $25^{\circ} \mathrm{C}$. The broth cultures were checked for purity before being harvested by centrifugation.

Isolation of DNA. Chromosomal DNA was isolated and purified according to the method described previously (Yoon et al., 1996).
Amplification and cloning of the RNase P RNA gene. The RNase P RNA gene was amplified using two primers described previously (Cho et al., 1998). Amplification was performed under the same conditions as those described previously (Yoon et al., 1997b). The PCR products were purified using the GeneClean II kit (Bio 101) and cloned into T-vector prepared with pBluescript (Stratagene) (Marchuk et al., 1991). General techniques for cloning were followed, as described previously (Kim et al., 1995).

Sequencing of the RNase P RNA gene. Nucleotide sequences were determined using the T7 Sequenase version 2.0 DNA sequencing kit (Amersham) with primers T3 (5'-ATTAACCCTCACTAAAG-3') and T7 (5'-TAATACGACTCACTATAGGGCGA-3'). In some cases, reactions with dITP and the SequiTherm EXCEL II DNA sequencing kit (Epicentre Technologies) were performed to relieve compression artifacts.

Data analysis. The sequences of the RNase P RNA genes determined in this study were aligned by using CLUSTAL $\mathrm{W}$ software (Thompson et al., 1994). Phylogenetic trees were inferred by using three tree-making algorithms, namely the neighbour-joining (Saitou \& Nei, 1987), maximum-likelihood (Felsenstein, 1981) and maximum-parsimony (Kluge \& Farris, 1969) methods, all of which were performed using the PHYLIP package (Felsenstein, 1993). Evolutionary distance matrices for the neighbour-joining method were

Table 1. Strains used in this study and accession numbers of RNase P RNA gene sequences

\begin{tabular}{|c|c|c|}
\hline Species & Source* & Accession no. \\
\hline Nocardioides albus & KCTC $9186^{\mathrm{T}}$ & AF110036 \\
\hline Nocardioides luteus & KCTC $9575^{\mathrm{T}}$ & AF110037 \\
\hline Nocardioides jensenii & KCTC $9134^{\mathrm{T}}$ & AF110038 \\
\hline Nocardioides plantarum & NCIMB $12834^{\mathrm{T}}$ & AF110039 \\
\hline Nocardioides simplex & КСТC $9106^{\mathrm{T}}$ & AF110040 \\
\hline Nocardioides pyridinolyticus & КСТC 0074BP & AF110041 \\
\hline Nocardioides nitrophenolicus & KCTC 0457BP & AF110042 \\
\hline 'Nocardioides flavus' & IFO $14396^{\mathrm{T}}$ & AF110043 \\
\hline 'Nocardioides fulvus' & JCM $3335^{\mathrm{T}}$ & AF110044 \\
\hline Kribbella flavida & IFO $14399^{\mathrm{T}}($ KCTC 9580 $)$ & AF110045 \\
\hline Kribbella sandramycini & ATCC $39419^{\mathrm{T}}\left(\right.$ KCTC $\left.9609^{\mathrm{T}}\right)$ & AF110046 \\
\hline Aeromicrobium erythreum & NRRL B-3381 & AF110047 \\
\hline Aeromicrobium fastidiosum & KCTC $9576^{\mathrm{T}}$ & AF110048 \\
\hline Terrabacter tumescens & KCTC $9133^{\mathrm{T}}$ & AF110049 \\
\hline Terracoccus luteus & DSM $44267^{T}$ & AF110050 \\
\hline Intrasporangium calvum & IFO $12989^{\mathrm{T}}($ KCTC 9796 $)$ & AF110051 \\
\hline Friedmanniella antarctica & DSM $11053^{\mathrm{T}}$ & AF110052 \\
\hline Microlunatus phosphovorus & JCM $9379^{\mathrm{T}}$ & AF110053 \\
\hline Microlunatus phosphovorus & JCM 9380 & AF110054 \\
\hline Propioniferax iпnосиа & DSM $8251^{\mathrm{T}}$ & AF110055 \\
\hline Luteococcus japonicus & IFO $12422^{\mathrm{T}}\left(\right.$ KCTC $\left.9794^{\mathrm{T}}\right)$ & AF110056 \\
\hline Luteococcus japonicus & IFO 15385 (КCTC 9795) & AF110057 \\
\hline Sporichthya polymorpha & IFO $12702^{\mathrm{T}}\left(\right.$ KCTC $\left.9797^{\mathrm{T}}\right)$ & AF110058 \\
\hline
\end{tabular}

* The following abbreviations are used: KCTC, Korean Collection for Type Cultures, Taejon, Korea; JCM, Japan Collection of Microorganisms, Institute of Physical and Chemical Research, Saitama, Japan; DSM, Deutsche Sammlung von Mikroorganismen und Zellkulturen, Braunschweig, Germany; NCIMB, National Collection of Industrial and Marine Bacteria, NCIMB, Aberdeen, UK; ATCC, American Type Culture Collection, Manassas, VA, USA; IFO, Institute for Fermentation, Osaka, Japan; NRRL, Agricultural Research Service Culture Collection, National Center for Agricultural Utilization Research, Peoria, IL, USA. 
generated with the algorithm of Jukes \& Cantor (1969) using the DNADIST program. The stability of relationships was assessed by a bootstrap analysis of 100 data sets by using the PHYLIP package.

\section{RESULTS AND DISCUSSION}

The genomic DNAs of strains used in this study were checked for contamination. The genomic DNAs of the Nocardioides species, the Aeromicrobium species and Terrabacter tumescens used in this work were those shown to be pure, by previous $16 \mathrm{~S}$ rDNA analysis (Yoon et al., 1998a). The DNAs extracted from other strains were identified as being uncontaminated, by direct determination of partial sequences of $16 \mathrm{~S}$ rDNAs. The gene encoding the RNase P RNA ( $r n p B$ ) was amplified by the PCR, using primers described previously (Cho et al., 1998), and was cloned before being sequenced. At least two to three clones containing RNase P RNA gene from each strain were sequenced to obtain exact sequence data and to confirm that the genuine sequence from each strain had been obtained.

The lengths of the RNase P RNA gene sequences determined ranged from $266 \mathrm{bp}$ (in Nocardioides luteus, 'Nocardioides flavus' IFO $14396^{\mathrm{T}}$ and 'Nocardioides fulvus' JCM $3335^{\mathrm{T}}$ ) to $326 \mathrm{bp}$ (in Nocardioides jensenii and Luteococcus japonicus). The nucleotide sequences corresponding to annealing regions of PCR primers were excluded from subsequent analyses, since their sequences may be different from the original sequences of the genes. The sequences determined correspond to the region between positions 78 and 346 (approx. 71\%), by comparison with the RNase P RNA gene (377 bp long) of Escherichia coli (Reed et al., 1982; Lawrence et al., 1987), and the region between positions 68 and 376 (approx. 75\%), by comparison with the RNase P RNA gene (413 bp) of Streptomyces bikiniensis (Morse \& Schmidt, 1992). The 5'-region of the RNase P RNA gene before the annealing region of the forward primer is not con-

Table 2. Percentage nucleotide similarity, with or without gaps included, for the RNase P RNA genes of the strains used in this study and Streptomyces bikiniensis

The values on the lower left are levels of nucleotide similarity and the values on the upper right are those with gaps included. Strains: 1, Nocardioides albus; 2, Nocardioides luteus; 3, Nocardioides jensenii; 4, Nocardioides plantarum; 5, Nocardioides simplex; 6, Nocardioides pyridinolyticus; 7, Nocardioides nitrophenolicus; 8, 'Nocardioides fulvus' JCM 3335 $;$ 9, Kribbella flavida; 10, Kribbella sandramycini; 11, Aeromicrobium erythreum; 12, Aeromicrobium fastidiosum; 13, Terrabacter tumescens; 14, Terracoccus luteus; 15, Intrasporangium calvum; 16, Friedmanniella antarctica; 17, Microlunatus phosphovorus JCM 9379 ; 18, Microlunatus phosphovorus JCM 9380; 19, Propioniferax innocua; 20, Luteococcus japonicus; 21, Sporichthya polymorpha; 22, Streptomyces bikiniensis.

\begin{tabular}{|c|c|c|c|c|c|c|c|c|c|c|c|c|c|c|c|c|c|c|c|c|c|c|}
\hline Strain & 1 & $2 *$ & 3 & 4 & 5 & 6 & 7 & 8 & 9 & 10 & 11 & 12 & 13 & 14 & 15 & 16 & 17 & 18 & 19 & $20 \dagger$ & 21 & 22 \\
\hline 1 & - & $89 \cdot 0$ & $66 \cdot 9$ & $70 \cdot 8$ & $80 \cdot 1$ & $71 \cdot 3$ & $76 \cdot 8$ & $89 \cdot 3$ & $68 \cdot 6$ & $71 \cdot 6$ & $67 \cdot 0$ & $71 \cdot 8$ & $72 \cdot 3$ & $71 \cdot 4$ & $70 \cdot 9$ & $67 \cdot 8$ & $67 \cdot 2$ & $67 \cdot 0$ & $72 \cdot 5$ & $67 \cdot 2$ & $56 \cdot 5$ & $70 \cdot 6$ \\
\hline $2 *$ & $94 \cdot 0$ & - & $64 \cdot 1$ & $69 \cdot 1$ & $78 \cdot 0$ & $69 \cdot 0$ & $78 \cdot 4$ & $99 \cdot 6$ & $69 \cdot 3$ & $69 \cdot 4$ & 65.9 & $67 \cdot 3$ & $70 \cdot 0$ & $67 \cdot 7$ & $71 \cdot 5$ & $66 \cdot 0$ & $66 \cdot 6$ & $66 \cdot 3$ & $75 \cdot 7$ & $64 \cdot 4$ & $58 \cdot 8$ & $69 \cdot 0$ \\
\hline 3 & $77 \cdot 6$ & $78 \cdot 6$ & - & $75 \cdot 1$ & $68 \cdot 4$ & $74 \cdot 3$ & $73 \cdot 3$ & $64 \cdot 7$ & $70 \cdot 4$ & $69 \cdot 1$ & $67 \cdot 2$ & $69 \cdot 0$ & $69 \cdot 6$ & $70 \cdot 5$ & $67 \cdot 9$ & $72 \cdot 6$ & $74 \cdot 0$ & $74 \cdot 3$ & $62 \cdot 8$ & $99 \cdot 7$ & $56 \cdot 5$ & $74 \cdot 2$ \\
\hline 4 & $80 \cdot 1$ & $79 \cdot 7$ & $81 \cdot 2$ & - & $77 \cdot 5$ & $72 \cdot 7$ & $78 \cdot 5$ & $69 \cdot 1$ & $67 \cdot 1$ & $66 \cdot 8$ & $72 \cdot 4$ & $66 \cdot 5$ & $70 \cdot 1$ & $71 \cdot 4$ & $71 \cdot 2$ & $73 \cdot 8$ & $75 \cdot 4$ & $76 \cdot 0$ & $70 \cdot 5$ & $75 \cdot 4$ & $60 \cdot 0$ & $73 \cdot 6$ \\
\hline 5 & $82 \cdot 4$ & $82 \cdot 4$ & $81 \cdot 7$ & $87 \cdot 2$ & - & 76.9 & $85 \cdot 8$ & $78 \cdot 3$ & $72 \cdot 7$ & $71 \cdot 0$ & $67 \cdot 2$ & 71.9 & 73.9 & $74 \cdot 4$ & $73 \cdot 0$ & $71 \cdot 8$ & $71 \cdot 1$ & $70 \cdot 9$ & $74 \cdot 4$ & $68 \cdot 7$ & $58 \cdot 7$ & $70 \cdot 9$ \\
\hline 6 & $78 \cdot 4$ & $78 \cdot 5$ & $83 \cdot 5$ & 82.9 & $83 \cdot 4$ & - & $73 \cdot 8$ & $68 \cdot 7$ & $73 \cdot 3$ & $73 \cdot 4$ & $66 \cdot 7$ & $68 \cdot 1$ & $71 \cdot 6$ & $72 \cdot 1$ & $69 \cdot 8$ & $72 \cdot 4$ & $74 \cdot 7$ & $75 \cdot 4$ & $67 \cdot 2$ & $74 \cdot 3$ & $58 \cdot 3$ & $73 \cdot 4$ \\
\hline 7 & $84 \cdot 6$ & $82 \cdot 0$ & $86 \cdot 0$ & 86.7 & $94 \cdot 7$ & $83 \cdot 2$ & - & $78 \cdot 8$ & $67 \cdot 1$ & $67 \cdot 4$ & $69 \cdot 0$ & $67 \cdot 0$ & $74 \cdot 4$ & $72 \cdot 3$ & $77 \cdot 9$ & $73 \cdot 7$ & $74 \cdot 3$ & $73 \cdot 2$ & $72 \cdot 3$ & $73 \cdot 6$ & $61 \cdot 1$ & $72 \cdot 6$ \\
\hline 8 & $94 \cdot 4$ & $99 \cdot 6$ & $79 \cdot 3$ & $79 \cdot 7$ & $82 \cdot 8$ & $78 \cdot 2$ & $82 \cdot 3$ & - & $68 \cdot 9$ & $69 \cdot 0$ & $66 \cdot 2$ & $67 \cdot 6$ & $70 \cdot 0$ & $67 \cdot 7$ & $71 \cdot 5$ & $66 \cdot 3$ & $66 \cdot 9$ & $66 \cdot 7$ & $76 \cdot 1$ & $64 \cdot 7$ & $58 \cdot 5$ & $68 \cdot 7$ \\
\hline 9 & $75 \cdot 7$ & $80 \cdot 8$ & $80 \cdot 4$ & $76 \cdot 7$ & $82 \cdot 1$ & $82 \cdot 6$ & $81 \cdot 8$ & $80 \cdot 4$ & - & $91 \cdot 0$ & $68 \cdot 1$ & $72 \cdot 3$ & $65 \cdot 2$ & $64 \cdot 0$ & $64 \cdot 3$ & $71 \cdot 4$ & $69 \cdot 8$ & $70 \cdot 2$ & $69 \cdot 9$ & $70 \cdot 1$ & $56 \cdot 7$ & $69 \cdot 2$ \\
\hline 10 & $79 \cdot 0$ & $80 \cdot 8$ & $79 \cdot 4$ & $75 \cdot 8$ & $80 \cdot 6$ & $83 \cdot 3$ & $81 \cdot 6$ & $80 \cdot 5$ & $92 \cdot 2$ & - & $66 \cdot 1$ & $74 \cdot 6$ & $66 \cdot 8$ & $63 \cdot 9$ & $65 \cdot 0$ & $71 \cdot 8$ & $70 \cdot 3$ & $70 \cdot 7$ & $68 \cdot 1$ & $69 \cdot 4$ & $55 \cdot 6$ & $68 \cdot 5$ \\
\hline 11 & $76 \cdot 4$ & $77 \cdot 4$ & $74 \cdot 8$ & $75 \cdot 5$ & $76 \cdot 8$ & $76 \cdot 2$ & $77 \cdot 0$ & $77 \cdot 7$ & $76 \cdot 0$ & $73 \cdot 7$ & - & $78 \cdot 6$ & $69 \cdot 6$ & $67 \cdot 9$ & $67 \cdot 9$ & $68 \cdot 3$ & $68 \cdot 7$ & $69 \cdot 6$ & $65 \cdot 8$ & $67 \cdot 2$ & $59 \cdot 6$ & $72 \cdot 2$ \\
\hline 12 & $79 \cdot 0$ & $78 \cdot 2$ & $77 \cdot 6$ & $75 \cdot 7$ & $82 \cdot 0$ & $77 \cdot 6$ & $80 \cdot 8$ & $78 \cdot 6$ & $74 \cdot 9$ & $77 \cdot 3$ & $88 \cdot 0$ & - & $67 \cdot 6$ & $64 \cdot 9$ & $63 \cdot 1$ & $69 \cdot 9$ & $68 \cdot 2$ & $68 \cdot 6$ & $67 \cdot 1$ & $69 \cdot 3$ & $57 \cdot 9$ & $67 \cdot 2$ \\
\hline 13 & $80 \cdot 6$ & 82.5 & $75 \cdot 3$ & $76 \cdot 8$ & $83 \cdot 2$ & $76 \cdot 8$ & $83 \cdot 3$ & $82 \cdot 5$ & $77 \cdot 0$ & $78 \cdot 8$ & $78 \cdot 0$ & $79 \cdot 5$ & - & $89 \cdot 7$ & $87 \cdot 7$ & $70 \cdot 4$ & $70 \cdot 4$ & $69 \cdot 7$ & $65 \cdot 0$ & $69 \cdot 9$ & $59 \cdot 2$ & $74 \cdot 4$ \\
\hline 14 & $80 \cdot 1$ & $79 \cdot 8$ & $76 \cdot 3$ & $78 \cdot 8$ & $84 \cdot 2$ & $78 \cdot 4$ & $81 \cdot 5$ & $79 \cdot 8$ & $77 \cdot 1$ & $77 \cdot 4$ & $76 \cdot 6$ & $77 \cdot 9$ & $91 \cdot 4$ & - & $84 \cdot 8$ & 66.9 & $68 \cdot 2$ & $67 \cdot 9$ & $65 \cdot 4$ & $70 \cdot 8$ & $58 \cdot 5$ & $73 \cdot 6$ \\
\hline 15 & $82 \cdot 2$ & $78 \cdot 8$ & $77 \cdot 1$ & $78 \cdot 8$ & $83 \cdot 6$ & $80 \cdot 4$ & $81 \cdot 6$ & $78 \cdot 8$ & $81 \cdot 1$ & 81.9 & 76.9 & $79 \cdot 2$ & $93 \cdot 8$ & $91 \cdot 3$ & - & $67 \cdot 5$ & $69 \cdot 7$ & $68 \cdot 8$ & $68 \cdot 3$ & $68 \cdot 2$ & $58 \cdot 8$ & 73.9 \\
\hline 16 & $76 \cdot 3$ & $77 \cdot 4$ & $76 \cdot 8$ & $81 \cdot 6$ & $82 \cdot 1$ & $77 \cdot 4$ & $82 \cdot 7$ & $77 \cdot 8$ & $80 \cdot 8$ & $81 \cdot 2$ & $76 \cdot 2$ & $77 \cdot 3$ & $75 \cdot 8$ & $73 \cdot 0$ & $76 \cdot 9$ & - & $80 \cdot 9$ & $80 \cdot 6$ & $66 \cdot 4$ & $72 \cdot 9$ & $60 \cdot 5$ & $73 \cdot 0$ \\
\hline 17 & $74 \cdot 5$ & $76 \cdot 3$ & $79 \cdot 6$ & $81 \cdot 0$ & $79 \cdot 5$ & $79 \cdot 6$ & $82 \cdot 6$ & $76 \cdot 7$ & $78 \cdot 8$ & 79.9 & $74 \cdot 0$ & $76 \cdot 2$ & $74 \cdot 2$ & $73 \cdot 8$ & $78 \cdot 2$ & $83 \cdot 8$ & - & $98 \cdot 7$ & $68 \cdot 7$ & $74 \cdot 3$ & $58 \cdot 4$ & $73 \cdot 6$ \\
\hline 18 & $74 \cdot 5$ & $76 \cdot 3$ & $79 \cdot 7$ & $81 \cdot 4$ & $79 \cdot 5$ & $80 \cdot 6$ & $80 \cdot 6$ & $76 \cdot 7$ & $79 \cdot 5$ & $80 \cdot 6$ & $74 \cdot 7$ & 76.9 & $73 \cdot 2$ & $73 \cdot 2$ & 76.9 & $83 \cdot 2$ & $99 \cdot 0$ & - & $67 \cdot 8$ & $74 \cdot 6$ & $58 \cdot 6$ & $73 \cdot 2$ \\
\hline 19 & 82.9 & $82 \cdot 2$ & $76 \cdot 3$ & $80 \cdot 1$ & $84 \cdot 0$ & $80 \cdot 9$ & $80 \cdot 1$ & $82 \cdot 6$ & $81 \cdot 3$ & $79 \cdot 2$ & $75 \cdot 0$ & $76 \cdot 8$ & $80 \cdot 3$ & $81 \cdot 4$ & $80 \cdot 2$ & $81 \cdot 0$ & $81 \cdot 4$ & $80 \cdot 7$ & - & $62 \cdot 8$ & $52 \cdot 4$ & $66 \cdot 4$ \\
\hline $20 \dagger$ & $77 \cdot 9$ & $78 \cdot 9$ & $99 \cdot 7$ & $81 \cdot 6$ & $82 \cdot 1$ & $83 \cdot 5$ & $86 \cdot 3$ & $79 \cdot 3$ & $80 \cdot 1$ & $79 \cdot 7$ & $74 \cdot 8$ & $77 \cdot 9$ & $75 \cdot 7$ & $76 \cdot 6$ & $77 \cdot 4$ & $77 \cdot 1$ & $79 \cdot 9$ & $80 \cdot 0$ & $76 \cdot 3$ & - & $56 \cdot 5$ & 73.9 \\
\hline 21 & 63.9 & $68 \cdot 4$ & $64 \cdot 8$ & $66 \cdot 2$ & $66 \cdot 1$ & $65 \cdot 1$ & $68 \cdot 0$ & $68 \cdot 1$ & $69 \cdot 7$ & $68 \cdot 4$ & $66 \cdot 8$ & $70 \cdot 9$ & $64 \cdot 9$ & $63 \cdot 7$ & $65 \cdot 1$ & $67 \cdot 4$ & $65 \cdot 7$ & $64 \cdot 5$ & $64 \cdot 3$ & $64 \cdot 8$ & - & $59 \cdot 3$ \\
\hline 22 & $78 \cdot 2$ & $80 \cdot 8$ & $78 \cdot 3$ & $80 \cdot 6$ & $80 \cdot 2$ & $79 \cdot 2$ & $81 \cdot 2$ & $80 \cdot 4$ & $81 \cdot 6$ & $79 \cdot 7$ & $80 \cdot 8$ & $78 \cdot 0$ & $76 \cdot 3$ & $76 \cdot 5$ & $79 \cdot 5$ & $77 \cdot 2$ & $77 \cdot 0$ & $76 \cdot 4$ & 81.9 & $78 \cdot 0$ & $65 \cdot 9$ & - \\
\hline
\end{tabular}

* Identical results were obtained for Nocardioides luteus and 'Nocardioides flavus' IFO 14396".

$\dagger$ Identical results were obtained for Luteococcus japonicus strains IFO $12422^{\mathrm{T}}$ and IFO 15385. 
served in sequence and length (Brown, 1998), unlike the $16 \mathrm{~S}$ rRNA gene. Therefore, it was difficult to design a primer for the region close to the $5^{\prime}$-end of the RNase P RNA gene. In some recent studies, most primers used for PCR amplification of the RNase P RNA gene also have been designed around the annealing regions of the PCR primers used in this study (Haas et al., 1996; Brown et al., 1996).

The alignment of the RNase P RNA gene sequences of all strains exhibited relatively conserved regions along with highly variable regions and nucleotide gapcontaining regions (data not shown). The regions corresponding to nt 116-138, 159-189 and 214-235, by comparison with the RNase P RNA gene sequence of Streptomyces bikiniensis, were relatively conserved, whereas the regions at nt 139-154, 239-275 and 350-376 were highly variable. The RNase P RNA gene sequence of Sporichthya polymorpha KCTC $9797^{\mathrm{T}}$ exhibited many mismatched nucleotides when compared with those of other strains, as is also demonstrated by nucleotide similarities (Table 2). When the nucleotide sequence of Sporichthya polymorpha KCTC $9797^{\mathrm{T}}$ was excluded from the alignment, the numbers of matched nucleotides were somewhat increased.

The mean RNase P RNA gene similarity value of LL$\mathrm{A}_{2} \mathrm{pm}$-containing strains used in this study was approximately $82 \pm 18 \%$ and the mean RNase P RNA gene-similarity value when gaps were included was approximately $76 \pm 24 \%$ (Table 2 ). The between-strain nucleotide similarities of RNase P RNA genes were mostly fewer than the corresponding 16S rDNA similarities. The nucleotide sequences of RNase $\mathrm{P}$ RNA genes are unlikely to be appropriate for comparisons at all taxonomic levels (e.g. between species, between genera and between families). In particular, the nucleotide similarities between most species belonging to the genus Nocardioides did not show conspicuous differences when compared with those between them and members of other genera; moreover, some species produced examples showing rather higher nucleotide similarities to members of other genera than to Nocardioides species (Table 2). It appears that the RNase P RNA gene does not necessarily show much higher sequence differences between higher-ranked taxa than between lowerranked taxa in the LL- $\mathrm{A}_{2}$ pm-containing strains used in this study. A phylogenetic tree based on the RNase P RNA gene sequences of all strains differed from that obtained using their 16S rDNA sequences. Therefore, phylogenetic trees based on RNase P RNA gene sequences of LL- $\mathrm{A}_{2} \mathrm{pm}$-containing strains used in this study were omitted because of the recognized limitations of RNase P RNA gene as a molecular clock.

The RNase P RNA gene sequences of validly described Nocardioides species were relatively divergent when compared with levels of $16 \mathrm{~S}$ rDNA similarity. The mean RNase P RNA gene similarity of the type strains of all validly described Nocardioides species was $85 \cdot 8 \pm 8 \cdot 2 \%$ (Table 2 ). The mean RNase P RNA gene

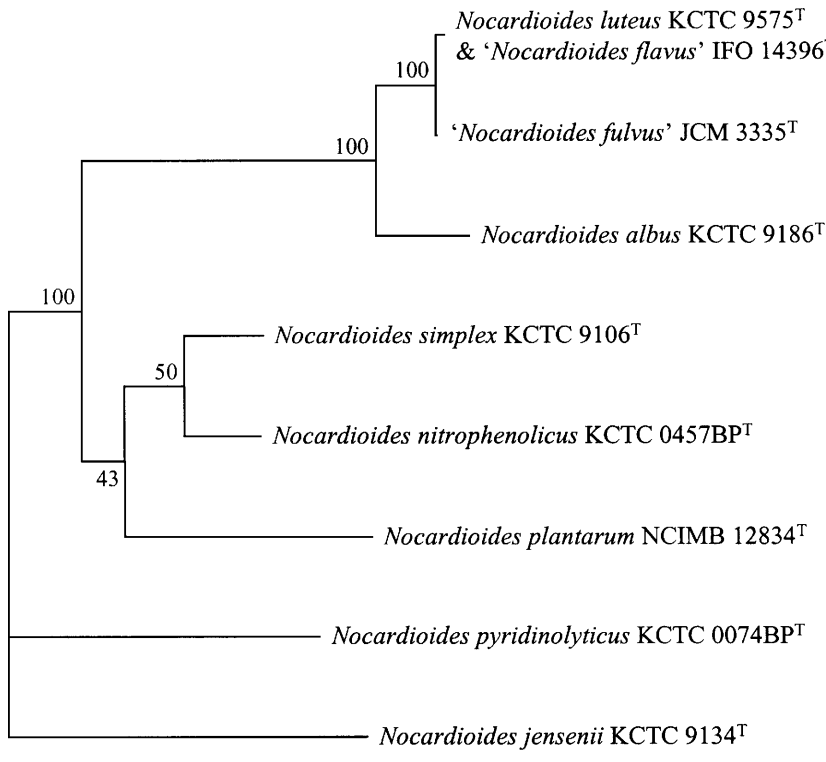

0.05

Fig. 1. Neighbour-joining tree showing the relationships among Nocardioides species based on RNase P RNA gene sequences. Bootstrap values are shown at the branch points. Bar, 5 nucleotide substitutions per 100 nucleotides.

similarity including gaps of the type strains of all valid Nocardioides species was approximately $76 \cdot 6 \pm 12 \cdot 5 \%$ (Table 2). The relationships between Nocardioides species, based on the RNase P RNA gene sequences, were examined with the trees inferred using the three different algorithms (Fig. 1). The topologies of the resultant trees were compared with the topology of a previously constructed tree based on 16S rDNA sequences (Yoon et al., 1998a). The close relationships between some species in the tree based on the RNase P RNA gene sequences (Fig. 1) are mostly consistent with the result obtained from 16S rDNA sequences (Yoon et al., 1998a). The type strains of Nocardioides albus and $N$. luteus were phylogenetic neighbours with a nucleotide similarity of $94 \%$. The clustering of Nocardioides simplex KCTC $9106^{\mathrm{T}}$ and Nocardioides nitrophenolicus KCTC 0457 $\mathrm{BP}^{\mathrm{T}}$ was supported with low bootstrap resampling values only when the neighbour-joining and maximum-likelihood methods were used. $N$. jensenii, Nocardioides plantarum and Nocardioides pyridinolyticus formed phylogenetic lineages distinct from each species. However, in a phylogenetic analysis including other taxa used in this study, Nocardioides species did not form a monophyletic cluster encompassed by the genus Nocardioides. $N$. pyridinolyticus and $N$. jensenii exhibited phylogenetic lineages independent of the cluster containing the type species of the genus Nocardioides, $N$. albus and most Nocardioides species. In particular, it was interesting that $N$. jensenii showed only a $1 \mathrm{bp}$ sequence difference with respect to $L$. japonicus. It was confirmed that the RNase P RNA 
gene sequences of $N$. jensenii and L. japonicus were correctly determined, by using repeated tests. The type strains of two invalidly described Nocardioides species, ' $N$. flavus' IFO $14396^{\mathrm{T}}$ and ' $N$. fulvus' JCM $3335^{\mathrm{T}}$, were used to infer the relationships with other Nocardioides species. ' $N$. flavus IFO $14396^{\mathrm{T}}$ had an RNase P RNA gene sequence identical to that of $N$. luteus and ' $N$. fulvus' JCM $3335^{\mathrm{T}}$ showed only a $1 \mathrm{bp}$ difference with respect to $N$. luteus. ' $N$. flavus' IFO $14396^{\mathrm{T}}$ has already been described as a strain of $N$. luteus (Prauser, 1989) and this has been confirmed recently by $16 \mathrm{~S}$ rDNA and $16 \mathrm{~S}-23 \mathrm{~S}$ ITS sequence analyses (Yoon et al., 1998a, b). 'N. fulvus' JCM 3335 was not clearly defined taxonomically until the $16 \mathrm{~S}$ rDNA and $16 \mathrm{~S}-23 \mathrm{~S}$ ITS sequences were determined. Therefore, RNase P RNA gene sequences also support previous data showing that ' $N$. flavus' IFO $14396^{\mathrm{T}}$ and ' $N$. fulvus' JCM $3335^{\mathrm{T}}$ are suitable for description as members of $N$. luteus. Another strain (IFO 14399) of ' $N$. fulvus' has been classified in a new genus (Kribbella) as Kribbella flavida, together with Nocardioides sp. ATCC 39419, classified as Kribbella sandramycini (Park et al., 1999). The two species of the new genus Kribbella formed a cluster independent of other strains used in this study and exhibited nucleotide similarity of $92 \cdot 2 \%$.

Two Aeromicrobium species formed a phylogenetic cluster that is clearly distinct from other taxa used in this study. The nucleotide similarity between the two species was $88 \%(78.6 \%$ when nucleotide gaps were included). The RNase P RNA genes of the two species are likely to be appropriate, as another genetic marker together with the 16S-23S ITS (Yoon et al., 1998b), for clarifying the relationship between the two species. The two Aeromicrobium species were compared with the members of the genus Nocardioides, a phylogenetic relative (Tamura \& Yokota, 1994; Yoon et al., 1998a). Aeromicrobium species formed a phylogenetic lineage distinguishable from the members of the genus Nocardioides and exhibited less than $80 \%$ nucleotide similarity to Nocardioides species, except in the case of the relationship between the type strains of Aeromicrobium fastidiosum and $N$. simplex (Table 2). Therefore, the RNase P RNA gene can be considered as a useful molecule that not only clearly differentiates Aeromicrobium species from Nocardioides species but also shows the correct variation between the two Aeromicrobium species.

Three genera, Intrasporangium, Terrabacter and Terracoccus, which belong to the family Intrasporangiaceae and comprise only single species, formed a cluster distinct from other taxa, as shown in a phylogenetic analysis based on $16 \mathrm{~S}$ rDNA sequences (Prauser et al., 1997). Intrasporangium calvum, Terrabacter tumescens and Terracoccus luteus exhibited relatively high nucleotide similarity $(91 \cdot 3-93.8 \%)$ to each other, despite being of different genera, when compared with results between different genera or different species used in this study. Phylogenetically close relatedness among the three genera has already been shown with 16S rDNA sequences (Prauser et al., 1997; Park et al., 1999). The RNase P RNA gene can be considered to be a more useful marker than $16 \mathrm{~S}$ rRNA for differentiation of the three taxa at the genus level. On the other hand, it was shown in an original description that Terracoccus luteus has two types of colonies, i.e. the rough form (DSM 44275) and the smooth form (DSM 44274) (Prauser et al., 1997). These forms were shown to be identical from a taxonomic point of view. We also isolated colonies of the rough form and the smooth form from the original culture (DSM $44267^{\mathrm{T}}$ ) and determined the RNase P RNA gene sequences from each colony type. The RNase P RNA gene sequences from the two types of colonies were found to be identical.

The genera Friedmanniella, Luteococcus, Microlunatus and Propioniferax, assigned to the family Propionibacteriaceae, also were compared. These genera also consist of single species. Among the four genera, Luteococcus japonicus formed a line of descent that is clearly different from the other three genera. As shown above, interestingly, L. japonicus had a nucleotide sequence nearly identical to that of $N$. jensenii. $F$. antarctica, $M$. phosphovorus and $P$. innocua formed a line of descent that can be considered as one phylogenetic cluster. Although the three genera form a phylogenetic cluster, they exhibit levels of nucleotide similarity $(81.0-83.8 \%)$ that makes possible their differentiation (Table 2).

Sporichthya polymorpha, one genus and one species that has been assigned to the family Sporichthyaceae, formed a line of descent that can be clearly distinguished from other LL-A $\mathrm{pm}_{2}$-acid-containing taxa. Sporichthya polymorpha exhibited the lowest levels of nucleotide similarity to all strains when compared with those between other strains (Table 2).

From the above results it is clear that the RNase $\mathrm{P}$ RNA gene was useful for indicating phylogenetic relationships between species belonging to a genus and relationships between several genera, being target genetic material that exhibits lower nucleotide similarity than the $16 \mathrm{~S}$ rRNA gene. Intraspecific variation of this gene was investigated for two species in this study. L. japonicus did not show intraspecific variation and two strains of $M$. phosphovorus showed relatively minor variation of $4 \mathrm{bp}$ differences. It was previously reported that the RNase P RNA genes of Saccharomonospora species also exhibited little or no intraspecific variation (Cho et al., 1998). The RNase $\mathrm{P}$ RNA gene was found to have sequence variation intermediate between that of $16 \mathrm{~S}$ rDNA and the $16 \mathrm{~S}-23 \mathrm{~S}$ ITS in data concerning the genera Nocardioides, Aeromicrobium and Kribbella (Yoon et al., 1998a, b), as was also shown for the genus Saccharomonospora (Cho et al., 1998). Generally, 16S rDNA sequences have been known to be appropriate for comparisons between species that are not closely related and between taxa above genus level, and 16S-23S ITS sequences are thought to be appropriate 
for indicating the relationships between closely related species and between strains belonging to a species. The RNase P RNA gene appears to be most suitable for indicating the relationships between species belonging to a genus and the relationships between several genera, because it is a genetic marker that shows sequence variation intermediate between that of $16 \mathrm{~S}$ rDNA and the 16S-23S ITS. Most genera among the LL-A ${ }_{2}$ pm-containing actinomycetes have only a single species representative. Therefore, RNase P RNA gene sequences may be very useful for differentiation between existing species and putatively novel species of LL- $\mathrm{A}_{2}$ pm-containing genera, as it is one of several sources of valuable data in the polyphasic approach to taxonomy. Nevertheless, the RNase P RNA gene may be inappropriate for determining phylogenetic relationships between some genera of LL- $\mathrm{A}_{2} \mathrm{pm}$-containing taxa. It has already been shown that Nocardioides species did not form a monophyletic cluster and that some Nocardioides species have a higher level of nucleotide similarity to other genera. However, other genera, except Nocardioides and Luteococcus, showed lines of descent distinct from each other, although the topology of the tree is different from that of the tree based on 16S rDNA sequences and some genera did not form phylogenetic lineages within the radiation encompassed by the family. In a previous study using the genus Saccharomonospora and some representative genera in a phylogenetic analysis, RNase P RNA gene sequences were found to be useful for differentiating between genera as well as between species belonging to a genus. Each genus not only showed distinct interspecific sequence differences, but also formed distinct phylogenetic lineages (Cho et al., 1998). Most genera in the phylogenetic tree obtained using RNase P RNA gene sequences from the RNase P database (Brown, 1998) are also shown to form distinct lines of descent.

It is still thought to be difficult to say whether it is worthwhile to use the RNase P RNA gene for inferring intergeneric relationships. To answer this question, it is necessary to extend the same approach to various genera. Even if subsequent tests prove that the RNase P RNA gene is less useful for comparisons of highranked taxa above genus level, it is clear that the RNase P RNA gene is useful for clearly differentiating species belonging to a genus. The species is the basic unit of bacterial systematics, but its definition has been a source of argument among microbiologists. For stable bacterial systematics, the application of a variety of target molecules or methods is very important because different information is obtained depending on the markers and methods used. The RNase P RNA gene showed greater sequence variation than $16 \mathrm{~S}$ rDNA, in spite of its smaller size. The characteristics of the RNase P RNA gene, i.e. that it is encoded from a single-copy locus (Haas et al., 1996) and is relatively conserved in size in bacteria (Pace \& Brown, 1995), can be very useful in the determination and analysis of nucleotide sequences. Thus, the RNase P RNA gene is a useful taxonomic marker that can be applied to a variety of taxa. Extension of the RNase P RNA gene database will contribute both to systematic study and the study of the function and secondary structure of the gene itself.

\section{ACKNOWLEDGEMENTS}

This work was supported by grants HS2321 and KG1295 from the Ministry of Science and Technology (MOST) of the Republic of Korea. We are grateful to Dr Yong Kook Shin for helpful discussion and to Seok-Seong Kang for practical assistance. We are also very grateful to the JCM (the Japan Collection of Microorganisms) and the IFO (the Institute for Fermentation, Osaka) for providing some of the strains used in this study.

\section{REFERENCES}

Amann, R., Ludwig, W. \& Schleifer, K. H. (1988). Beta-subunit of ATP-synthase: a useful marker for studying the phylogenetic relationship of eubacteria. J Gen Microbiol 134, 2815-2821.

Baylis, H. A. \& Bibb, M. J. (1988). Organization of the ribosomal RNA genes in Streptomyces coelicolor A3(2). Mol Gen Genet 211, 191-196.

Brown, J. W. (1998). The ribonuclease P database. Nucleic Acids Res 26, 351-352.

Brown, J. R., Masuchi, Y., Robb, F. T. \& Doolittle, W. F. (1994). Evolutionary relationships of bacterial and archaeal glutamine synthetase genes. J Mol Evol 38, 566-576.

Brown, J. W., Nolan, J. M., Haas, E. S., Rubio, M. A. T., Major, F. \& Pace, N. R. (1996). Comparative analysis of ribonuclease P RNA using gene sequences from natural microbial populations reveals tertiary structural elements. Proc Natl Acad Sci USA 93, 3001-3006.

Cho, M., Yoon, J.-H., Kim, S.-B. \& Park, Y.-H. (1998). Application of the ribonuclease P (RNase P) RNA gene sequence for phylogenetic analysis of the genus Saccharomonospora. Int $J$ Syst Bacteriol 48, 1223-1230.

Collins, M. D., Dorsch, M. \& Stackebrandt, E. (1989). Transfer of Pimelobacter tumescens to Terrabacter gen. nov. as Terrabacter tumescens comb. nov. and of Pimelobacter jensenii to Nocardioides as Nocardioides jensenii comb. nov. Int J Syst Bacteriol 39, 1-6.

Collins, M. D., Cockcroft, S. \& Wallbanks, S. (1994). Phylogenetic analysis of a new LL-diaminopimelic acid-containing coryneform bacterium from herbage, Nocardioides plantarum sp. nov. Int J Syst Bacteriol 44, 523-526.

Felsenstein, J. (1981). Evolutionary trees from DNA sequences: a maximum likelihood approach. J Mol Evol 17, 368-376.

Felsenstein, J. (1993). PHYLIP: Phylogenetic Inference Package, version 3.5. Seattle: University of Washington.

Fox, G. E., Wisotzkey, J. D. \& Jurtshuk, P., Jr (1992). How close is close: $16 \mathrm{~S}$ rRNA sequence identity may not be sufficient to guarantee species indentity. Int J Syst Bacteriol 42, 166-170.

Haas, E. S., Banta, A. B., Harris, J. K., Pace, N. R. \& Brown, J. W. (1996). Structure and evolution of ribonuclease P RNA in grampositive bacteria. Nucleic Acids Res 24, 4775-4782.

Hain, T., Ward-Rainey, N., Kroppenstedt, R. M., Stackebrandt, E. \& Rainey, F. A. (1997). Discrimination of Streptomyces albidoflavus strains based on the size and number of 16S-23S ribosomal DNA intergenic spacers. Int $J$ Syst Bacteriol 47, 202-206. 
Hofle, M. (1990). Transfer RNAs as genotypic fingerprints of eubacteria. Arch Microbiol 153, 299-304.

Johnson, J. L. (1991). DNA reassociation experiments. In Nucleic Acid Techniques in Bacterial Systematics, pp. 21-44. Edited by E. Stackebrandt \& M. Goodfellow. Chichester: Wiley.

Jukes, T. H. \& Cantor, C. R. (1969). Evolution of protein molecules. In Mammalian Protein Metabolism, vol. 3, pp. 21-132. Edited by H. N. Munro. New York: Academic Press.

Kalakoutskii, L. V., Kirillova, I. P. \& Krassilnikov, N. A. (1967). A new genus of the Actinomycetales - Intrasporangium gen. nov. $J$ Gen Microbiol 48, 79-85.

Kamla, V., Henrich, B. \& Hadding, U. (1996). Phylogeny based on elongation factor $\mathrm{Tu}$ reflects the phenotypic features of mycoplasma better than that based on 16S rRNA. Gene 171, 83-87.

Keddie, R. M., Leask, B. G. S. \& Grainger, J. M. (1966). A comparison of coryneform bacteria from soil and herbage: cell wall composition and nutrition. J Appl Bacteriol 29, 17-43.

Kim, S.-B., Yoon, J.-H., Kim, H., Lee, S. T., Park, Y.-H. \& Goodfellow, M. (1995). A phylogenetic analysis of the genus Saccharomonospora conducted with $16 \mathrm{~S}$ rRNA gene sequences. Int J Syst Bacteriol 45, 351-356.

Kluge, A. G. \& Farris, F. S. (1969). Quantitative phyletics and the evolution of anurans. Syst Zool 18, 1-32.

Lawrence, N. P., Richman, A., Amini, R. \& Altman, S. W. (1987). Heterologous enzyme function in Escherichia coli and the selection of genes encoding the catalytic RNA subunit of RNase P. Proc Natl Acad Sci USA 84, 6825-6829.

Leblond-Bourget, N., Philippe, H., Mangin, I. \& Decaris, B. (1996). $16 \mathrm{~S}$ rRNA and $16 \mathrm{~S}$ to $23 \mathrm{~S}$ internal transcribed spacer sequence analyses reveal inter- and intraspecific Bifidobacterium phylogeny. Int J Syst Bacteriol 46, 102-111.

Lechevalier, M. P., Lechevalier, H. \& Holbert, P. E. (1968). Sporichthya, un nouveau genre de Streptomycetaceae. Ann Inst Pasteur (Paris) 114, 277-286.

Marchuk, D., Drumm, M., Saulino, A. \& Collins, F. S. (1991). Construction of T-vectors, a rapid and general system for direct cloning of unmodified PCR products. Nucleic Acids Res 19, 1154.

Miller, E. S., Woese, C. R. \& Brenner, S. (1991). Description of the erythromycin-producing bacterium Arthrobacter sp. strain NRRL B-3381 as Aeromicrobium erythreum gen. nov., sp. nov. Int J Syst Bacteriol 41, 363-368.

Morse, D. P. \& Schmidt, F. J. (1992). Sequences encoding the protein and RNA components of ribonuclease $\mathrm{P}$ from Streptomyces bikiniensis var. zorbonensis. Gene 117, 61-66.

Nakamura, K., Hiraishi, A., Yoshimi, Y., Kawaharasaki, M., Masuda, K. \& Kamagata, Y. (1995). Microlunatus phosphovorus gen. nov., sp. nov., a new gram-positive polyphosphateaccumulating bacterium isolated from activated sludge. Int $J$ Syst Bacteriol 45, 17-22.

Pace, N. R. \& Brown, J. W. (1995). Evolutionary perspective on the structure and function of ribonuclease $\mathrm{P}$, a ribozyme. $J$ Bacteriol 177, 1919-1928.

Park, Y.-H., Yoon, J.-H., Shin, Y. K., Suzuki, K., Kudo, T., Seino, A., Kim, H.-J., Lee, J.-S. \& Lee, S. T. (1999). Classification of 'Nocardioides fulvus' IFO 14399 and Nocardioides sp. ATCC 39419 in Kribbella gen. nov., as Kribbella flavida sp. nov. and Kribbella sandramycini sp. nov. Int J Syst Bacteriol 49, 743-752.

Pernodet, J.-L., Boccard, F., Alegre, M.-T., Gagnat, J. \& Guérineau, M. (1989). Organization and nucleotide sequence analysis of a ribosomal RNA gene cluster from Streptomyces ambofaciens. Gene 79, 33-46.

Prauser, H. (1976). Nocardioides, a new genus of the order Actinomycetales. Int J Syst Bacteriol 26, 58-65.

Prauser, H. (1989). Genus Nocardioides Prauser 1976, 61 ${ }^{\mathrm{AL}}$. In Bergey's Manual of Systematic Bacteriology, vol. 4, pp. 2371-2375. Edited by S. T. Williams, M. E. Sharpe \& J. G. Holt. Baltimore: Williams \& Wilkins.

Prauser, H., Schumann, P., Rainey, F. A., Kroppenstedt, R. M. \& Stackebrandt, E. (1997). Terracoccus luteus gen. nov., sp. nov., an LL-diaminopimelic acid-containing coccoid actinomycete from soil. Int J Syst Bacteriol 47, 1218-1224.

Reed, R. E., Baer, M. F., Guerrier-Takada, C., Donis-Keller, H. \& Altman, S. (1982). Nucleotide sequence of the gene encoding the RNA subunit (M1 RNA) of ribonuclease P from Escherichia coli. Cell 30, 627-636.

Saitou, N. \& Nei, M. (1987). The neighbor-joining method: a new method for reconstructing phylogenetic trees. Mol Biol Evol 4, 406-425.

Schumann, P., Prauser, H., Rainey, F. A., Stackebrandt, E. \& Hirsch, P. (1997). Friedmanniella antarctica gen. nov., sp. nov., an LL-diaminopimelic acid-containing actinomycete from Antarctic sandstone. Int J Syst Bacteriol 47, 278-283.

Stackebrandt, E. \& Goebel, B. M. (1994). Taxonomic note: a place for DNA-DNA reassociation and 16S rRNA sequence analysis in the present species definition in bacteriology. Int $J$ Syst Bacteriol 44, 846-849.

Stackebrandt, E., Rainey, F. A. \& Ward-Rainey, N. L. (1997). Proposal for a new hierarchic classification system, Actinobacteria classis nov. Int J Syst Bacteriol 47, 479-491.

Swanson, D. S., Kapur, V., Stockbauer, K., Pan, X., Frothingham, R. \& Musser, J. M. (1997). Subspecific differentiation of Mycobacterium avium complex strains by automated sequencing of a region of the gene ( $h s p 65$ ) encoding a 65-kilodalton heat shock protein. Int J Syst Bacteriol 47, 414-419.

Tamura, T. \& Yokota, A. (1994). Transfer of Nocardioides fastidiosa Collins and Stackebrandt 1989 to the genus Aeromicrobium as Aeromicrobium fastidiosum comb. nov. Int J Syst Bacteriol 44, 608-611.

Tamura, T., Takeuchi, M. \& Yokota, A. (1994). Luteococcus japonicus gen. nov., a new gram-positive coccus with LLdiaminopimelic acid in the cell wall. Int J Syst Bacteriol 44, 348-356.

Thompson, J. D., Higgins, D. G. \& Gibson, T. J. (1994). CLUSTAL $\mathrm{W}$ : improving the sensitivity of progressive multiple sequence alignment through sequence weighting, position specific gap penalties and weight matrix choice. Nucleic Acids Res 22, 4673-4680.

Valsangiacomo, C., Balmelli, T. \& Piffaretti, J.-C. (1997). A phylogenetic analysis of Borrelia burgdorferi sensu lato based on sequence information from the $h b b$ gene, coding for a histone-like protein. Int J Syst Bacteriol 47, 1-10.

Vandamme, P., Pot, B., Gillis, M., De Vos, P., Kersters, K. \& Swings, J. (1996). Polyphasic taxonomy, a consensus approach to bacterial systematics. Microbiol Rev 60, 407-438.

Wayne, L. G., Brenner, D. J., Colwell, R. R. \& 9 other authors (1987). International Committee on Systematic Bacteriology. Report of the ad hoc committee on reconciliation of approaches to bacterial systematics. Int J Syst Bacteriol 37, 463-464.

Woese, C. R. (1987). Bacterial evolution. Microbiol Rev 51, 221-271. 
Woese, C. R. \& Fox, G. E. (1977). Phylogenetic structure of the prokaryotic domain: the primary kingdoms. Proc Natl Acad Sci U S A 74, 5088-5090.

Yokota, A., Tamura, T., Takeuchi, M., Weiss, N. \& Stackebrandt, E. (1994). Transfer of Propionibacterium innocuum Pitcher and Collins 1991 to Propioniferax gen. nov. as Propioniferax innocua comb. nov. Int J Syst Bacteriol 44, 579-582.

Yoon, J.-H., Kim, H., Kim, S.-B., Kim, H.-J., Kim, W. Y., Lee, S. T., Goodfellow, M. \& Park, Y.-H. (1996). Identification of Saccharomonospora strains by the use of genomic DNA fragments and rRNA gene probes. Int J Syst Bacteriol 46, 502-505.

Yoon, J.-H., Lee, S. T., Kim, S.-B., Goodfellow, M. \& Park, Y.-H. (1997a). Inter- and intraspecific genetic analysis of the genus Saccharomonospora with $16 \mathrm{~S}$ to $23 \mathrm{~S}$ ribosomal DNA (rDNA) and $23 \mathrm{~S}$ to $5 \mathrm{~S}$ rDNA internally transcribed spacer sequences. Int J Syst Bacteriol 47, 661-669.

Yoon, J.-H., Lee, S. T., Kim, S.-B., Kim, W. Y., Goodfellow, M. \& Park, Y.-H. (1997b). Restriction fragment length polymorphism analysis of PCR-amplified 16S ribosomal DNA for rapid identification of Saccharomonospora strains. Int J Syst Bacteriol 47, 111-114.

Yoon, J.-H., Rhee, S.-K., Lee, J.-S., Park, Y.-H. \& Lee, S. T. (1997c). Nocardioides pyridinolyticus sp. nov., a pyridine-degrading bacterium isolated from the oxic zone of an oil shale column. Int J Syst Bacteriol 47, 933-938.

Yoon, J.-H., Lee, S. T. \& Park, Y.-H. (1998a). Inter- and intraspecific phylogenetic analysis of the genus Nocardioides and related taxa based on $16 \mathrm{~S}$ rDNA sequences. Int $J$ Syst Bacteriol 48, 187-194.

Yoon, J.-H., Lee, S. T. \& Park, Y.-H. (1998b). Genetic analyses of the genus Nocardioides and related taxa based on $16 \mathrm{~S}-23 \mathrm{~S}$ rDNA internally transcribed spacer sequences. Int $J$ Syst Bacteriol 48, 641-650.

Yoon, J.-H., Cho, Y.-G., Lee, S. T., Suzuki, K., Nakase, T. \& Park, Y.-H. (1999). Nocardioides nitrophenolicus sp. nov., a p-nitrophenol-degrading bacterium. Int J Syst Bacteriol 49, 675-680. 